\title{
Kömür Bileșenlerinin Kalorifik Değer Üzerindeki Etkisi Üzerine Değerlendirme
}

\section{Evaluation of Coal Components-Coal Calorific Value Relationship}

\author{
FERIDUN BOYLU*1, IBRAHIM ETHEM KARAAĞAÇLIOĞLU' \\ ${ }^{1}$ Istanbul Teknik Üniversitesi, Maden Fakültesi, Cevher Hazırlama Mühendisliği Bölümü, Maslak, Sarıyer, İstanbul, \\ Türkiye
}

Geliș (received) : 14 Ağustos (August) 2018

Kabul (accepted) : 22 Kasım (November) 2018

öz

Kömür kalitesi genellikle, kül içeriği ile ifade edilmektedir. Kömür ısıl değerinin büyük oranda kül yapıcı madde içeriği tarafından kontrol edildiği bilinmektedir. Ancak, kömür kül içeriğinin yanı sıra, kısa kömür ve elementel analiz bileșenleri ve ilave olarak kömür petrografisinin de kömür ısıl değeri üzerindeki etkisi önemlidir. Sonuç olarak her ne kadar kül içeriğinin kömür kalitesi üzerinde etkisi büyük olsa da, asıında kömür kalitesinin, kül içeriği, ısıl değer ve kömürü meydana getiren orijinal bitkinin kökeni yani kömür petrografisinin bir kombinasyonu olarak ortaya çıktığı bir gerçektir. Öyle ki, kömür yıkama ișlemleri sonrasında, elde edilen atığın (șistin) değerlendirilmesi sadece kül içeriği ile yapıldığında, zenginleștirmenin etkinliği ile ilgili ciddi değerlendirilme yanııșığı söz konusu olmaktadır. Buna ilave olarak, online kömür analizi için programlar yazııırken dahi, kalorifik değer-kül içeriği ilișkisi, çoğu uygulamalarda global olarak değerlendirilmekte ve bu da ölçüm doğruluğunu etkilemektedir. Kül-kalorifik değer ilișkisi ve kömür yıkama tesis atıklarının kalitesinin değerlendirilmesi üzerine yapılan yanlıș ve eksik tanımlamalarla ilgili örnekler daha da çoğaltılabilir. Bu sebeple, kömür ve kömürün yapısal özellikleri, kül yapıcı madde ve kül içeriği ilișkisinin çok daha detaylı bir șekilde örneklendirildiği çalıșmalara intiyaç duyulmaktadır.

Bu çalıșmada, kömür bileșenleri-kömür ısıl değeri ve kül yapııı madde-kül içeriği ilișkisi, bazı Türk kömür örnekleri üzerinde değerlendirilerek tartıșılmıștır.

Anahtar Kelimeler: Kömür, kül içeriği, kısa kömür analizi, elementel analiz, üst ısıl değer modeli.

\begin{abstract}
Coal quality is generally defined based on the ash contents. It is well known that the calorific value of coal is negatively affected by the increase on ash contents. However, the attitude of calorific value is not only dependent on ash content, it is also controlled by proximate and ultimate coal analysis components such as moisture, volatile matter, fixed carbon, total carbon, hydrogen, nitrogen and sulfur content. In addition, coal petrography is also worth to be counted as a factor controlling the calorific values of coal. In this study the relationships between the factors of proximate and ultimate analysis components and calorific value of coals have been discussed through some known coal examples from Turkey.
\end{abstract}

Keywords: Coal, ash content, proximate analysis, ultimate analysis, gross calorific value model.

\footnotetext{
${ }^{*}$ F. Boylu

e-posta: boylu@itu.edu.tr
} 


\section{GENEL BILGILER}

\section{Kömür Bileșenleri}

Kömür yapı itibarıyla heterojen yapıda olup, organik ve inorganik madde ve nemden olușan kompozisyona sahip, yanabilen ve yandığında ısı veren bir kayaçtır (Ateșok, 2004).

Kömürün organik yapısını karbon olușturmakta, inorganik maddelerin bașlıcaları kil, kuvars, kalsit ve kükürt olmak üzere, gerek kömürün olușumu sırasında, kömürün orijinal kısmı olan bitkisel yapısından gelen, gerekse de kömürün oluștuğu bataklık ortamdaki reaksiyonlar sonucu olușan veya kömür olușumu sırasında doğa etkileri ile dıșarıdan gelip kömür yataklanması içerisine giren mineral maddelerden olușmaktadır (Șekil 1).

Kömür analizleri genelde kısa kömür analizleri (proximate analiz) ve elementel analiz (ultimate analiz) olmak üzere iki farklı șekilde yapılır/tanımlanır.

Kısa kömür analizleri genellikle; nem, kül, uçucu madde, kükürt (toplam ve yanabilir), sabit karbon ve ısıl değer özelliklerinin belirlenmesine yönelik yapılırken, elementel analiz; kükürt, N, C, O gibi, katı ya da gaz halindeki bileșiklerin belirlenmesine yönelik yapılmaktadır.
Kısa analiz bileșenleri değerlendirilirse;

Sabit karbon: yanma ünitesinde, kömür yapısından uçucu madde çıktıktan sonra geriye kalan katı yakıttır. Büyük oranda karbon ve yanma sırasında emisyona dönüșmemiș olan hidrojen, oksijen, sülfür ve azot gibi bileșikleri içermektedir. Sabit karbon ısıl değerin kabaca tahmin edilmesine yardımcı olur.

Uçucu madde: metan, hidrokarbonlar, hidrojen ve karbon monoksit ve kömürün içerisindeki $\mathrm{CO}_{2}$ ve azot gibi yanmayan gazlardan olușur. Dolayısıyla, uçucu madde gazlı yakıtların varlığını gösteren bir indekstir. Tipik olarak kömür rankına bağlı olarak 5-50 arasında bulunur. Yanma sırasında, doğrusal orantılı olarak alev boyutunu yükseltir ve tutușmaya kolaylık sağlar. Minimum fırın yüksekliğinin belirlenmesinde etkilidir. İkincil hava ihtiyacı ve dağıtımı unsurlarını doğrudan etkiler.

Kül miktarı: Kömürün yapısında bulunan yanmayan kısmı olușturur. Handling ve yakma kapasitesini düșürür. Yanma etkinliğini ve boyler kullanımını olumsuz etkiler. Yanma sırasında ve sonrasında klinker ve cüruf olușumuna sebebiyet verir.

Nem: Kömürün ısıl değerinin düşürür. Yakma sırasında, buharlaşması ve buharın aşırı ısıtılması sebebiyle ısıl kayıpları arttırır. Radyasyon ISı transferine yardımcı olur.

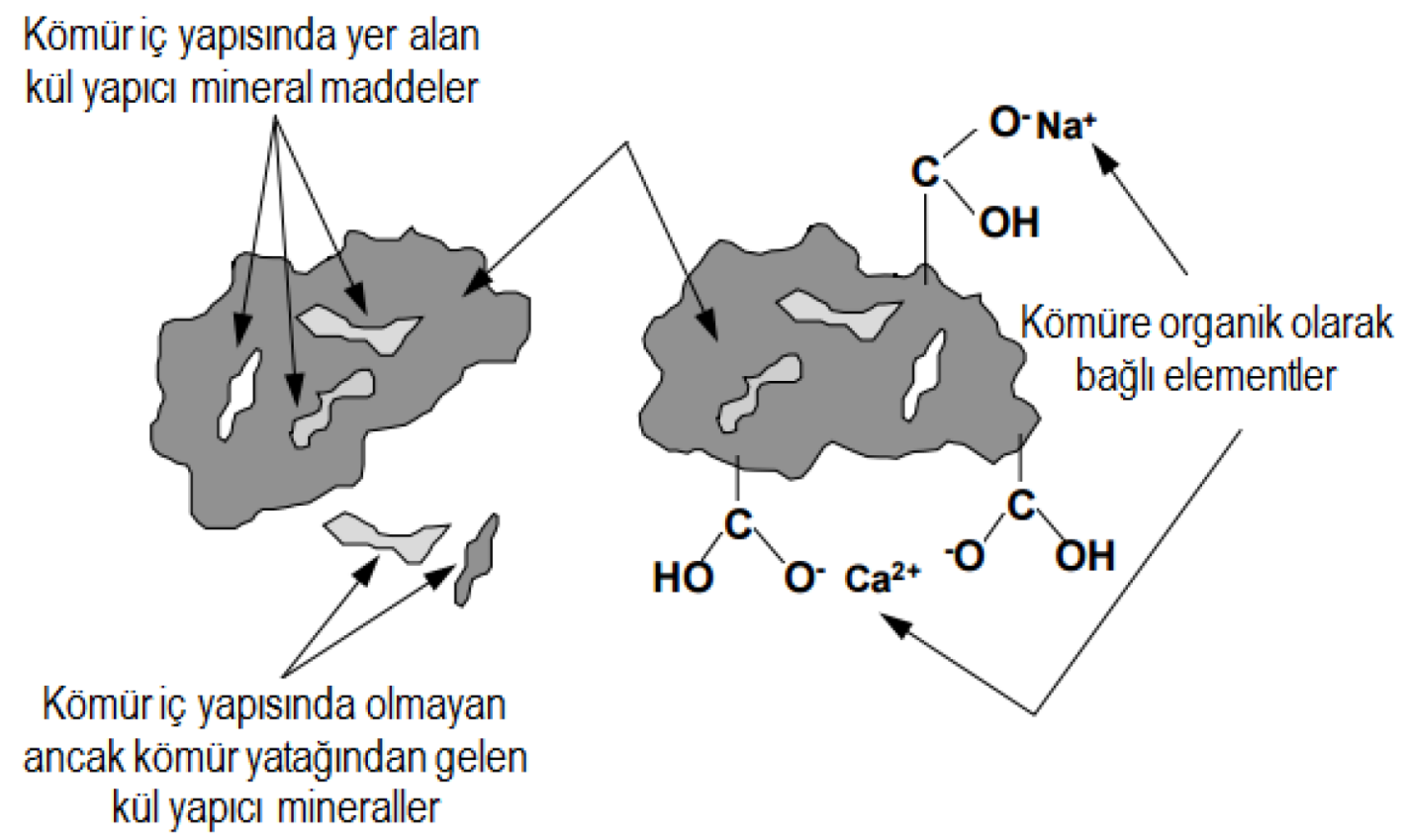

Șekil 1. Kömürle birlikte bulunan Minerallerin ve diğer inorganik bileșenlerin gösterimi (Benson, 1993).

Figure 1. Illustration of Coal and Ash Forming Minerals and Other Inorganic Constituents (Benson, 1993). 
Kükürt içeriği: Klinker olușturma ve cüruf olușturma eğilimini arttıır. Baca ve hava ısıtıcıları ve ekonomizer gibi diğer ekipmanların korozyonuna sebebiyet verir. Akıcı gaz çıkıș sıcaklığııı sınırlandııır.

Elementel analiz bileșenleri karbon, hidrojen, oksijen, sülfür vs gibi elementel kimyasal bileșenleri içerir. Yakma için gerekli olan hava miktarının, yanma gazlarını hacmi ve kompozisyonunun belirlenmesinde önemli rol oynar.

Elementel analiz bileșenleri ve kısa analiz bileșenleri arasındaki ilișki Çizelge 1'de verilmiștir.

Gerek kısa gerekse elementel kömür analizleri, toplam nem (Kuru baz) , yüzey nemi (havada kuru baz) ve külün olmadığı (kuru külsüz baz) șartlara göre ya da orijinal kömüre göre (toplam nem ve külü içerecek șekilde) ifade edilmektedir.

Kömür bileșenleri ve yukarıda anlatılan kuru, havada kuru ve kuru külsüz baz ifadelerinin daha belirgin tanımlaması Șekil 2. de verilmiștir.

\section{Kömür bileșenlerinin Isıl değer üzerindeki etkisi}

\section{Kül-Isıl değer ilișkisi}

Kül, kömür yapısında inorganik maddeyi olușturmakta ve yanabilir özellikte olmadığı için kömürün ısıl değerini düșürmektedir.

\section{Nem-Isıl değer İlișkisi}

Nem, kömür yapısının ana bileșenlerinden olup, genellikle yüzey nemi ve bünye nemi olarak ifade edilmektedir. Nem, yanabilir özellikte olmadığı ve kömürün yanması sırasında buharlaștırma ișlemi için enerji gerektirdiğinden, kömürün ısıl değerini düșürmektedir. Pratik uygulamalarda her bir \% nem, $\% 1$ kül içeriği gibi kabul edilmektedir.

\section{Kısa analiz bileșenleri-ısıl değer ilișkisi}

Majumder ve ark. (2008) yaptıkları çalıșmada kömürün kısa analizlerinin üst ısıl değerin büyüklüğü üzerindeki etkisini özetlemișlerdir. Majumder ve ark. yaptığı çalıșmada yer aldığı șekilde, kayda değer bazı modeller așağıda verilmiștir;

Küçükbayrak vd. (1991) (kuru baza göre);

$G C V=76.56-1.3\left(V_{M}+A\right)+0.00703\left(V_{M}+A\right)^{2}(1)$

$G C V=76.56-1.3\left(V_{M}+A\right)+0.00703\left(V_{M}+A\right)^{2}$

Demirbaș (1997) (Orijinal baza göre);

$$
\begin{aligned}
& G C V=0.196 F_{C}+14.119 \\
& G C V=0.196 F_{C}+14.119
\end{aligned}
$$

Parikh ve diğ. (2005), (kuru baza göre)

$$
G C V=0.353 F_{C}+0.1559 V_{M}-0.0078 \mathrm{~A}
$$

Çizelge 1. Elementel analiz bileșenleri ve kısa analiz bileșenleri arasındaki ilișki.

Table 1. Relationship between ultimate and proximate analyses constituents.

\begin{tabular}{cc}
\hline Bileșen & Model \\
\hline $\mathrm{C}, \%$ & $0.97 \mathrm{C}+0.7\left(\mathrm{~V}_{\mathrm{M}}-0.1 \mathrm{~A}\right)-\mathrm{M}(0.6-0.01 \mathrm{M})$ \\
$\mathrm{H}, \%$ & $0.036 \mathrm{C}+0.086\left(\mathrm{~V}_{\mathrm{M}}-0.1 \mathrm{~A}\right)-0.0035 \mathrm{M}^{2}(1.0 .02 \mathrm{M})$ \\
$\mathrm{N}_{2}, \%$ & $2.10-0.020 \mathrm{~V}_{\mathrm{M}}$ \\
$\mathrm{C}$ & Sabit Karbon, \% \\
$\mathrm{A}$ & Kül, \% \\
$\mathrm{V}_{\mathrm{M}}$ & Uçucu Madde, \% \\
$\mathrm{M}$ & Nem, \% \\
\hline
\end{tabular}

Not: Yukarıdaki yaklașım \% 15'den fazla nem içeren kömürler için geçerlidir. 


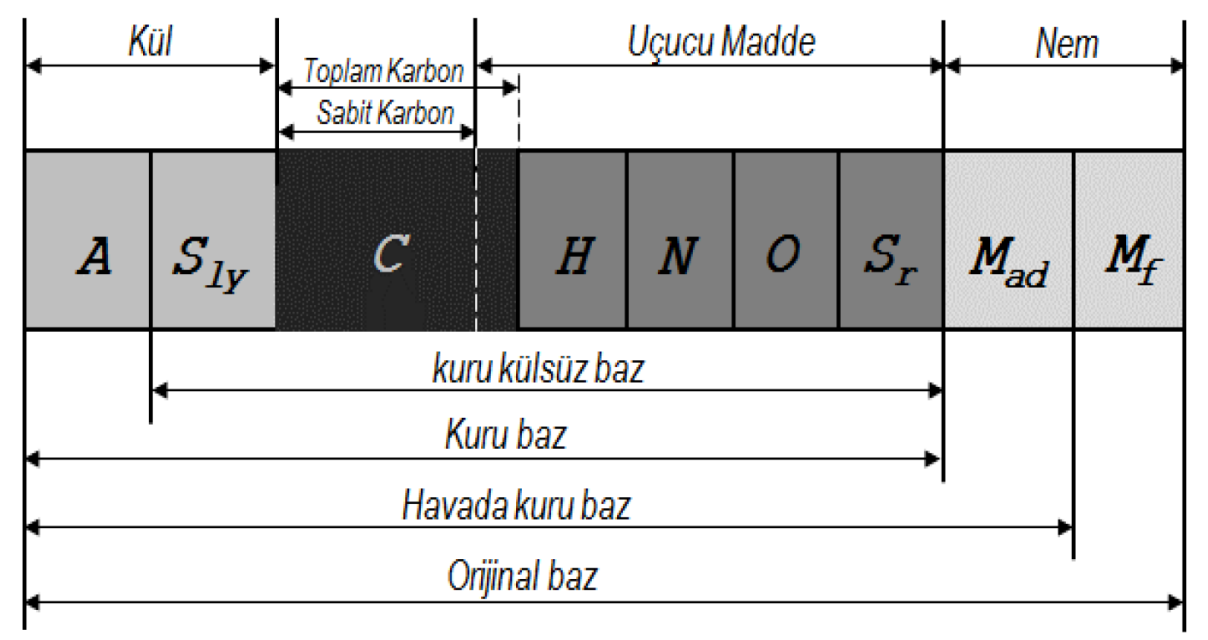

Șekil 2. Kömür Bileșenleri ve kömür Analizlerin Farklı Bazlarda Değerlendirilmesi (Wen ve diğ., 2017).

Figure 2. Evaluation of Relationship Between Coal Constituents and Coal Analyses (Wen ve diğ., 2017).

Majumder ve diğ. (2008) (orijinal baza göre)

$G C V=-0.03 A-0.11 M+0.33 V_{M}+0.35 F_{C}$

$G C V=-0.03 A-0.11 M+0.33 V_{M}+0.35 F_{C}$

Buna benzer birçok model çalıșmaları, Wen ve diğerlerinin (2017) yaptığı çalıșmada daha detaylı olarak bulunabilir. Wen'in çalıșmasından alınan ve regresyon katsayısı yüksek olan bazı modeller Çizelge 2'de verilmektedir.

\section{Elementel analiz - ısıl değer ilișkisi}

Bununla birlikte, Kömürün elementel analizlerinde yer alan bileșiklerin de üst ısıl değerin büyüklüğünde etkili olduğu ifade edilmektedir. Wen ve diğ.(2017), yaptıkları çalıșmada, bugüne kadar yapılııs olan elementel analiz bileșenleri-üst ısıl değer modellerini özetlemișlerdir. Bu çalıșmadan alınan ve regresyon katsayısı yüksek olan bazı modeller Çizelge 3 'de verilmiștir.

\section{Kömür Maseralleri - ısıl değer ilișkisi}

Kömür yapı itibarıyla organik ve inorganik madde ve sudan meydana gelen bir kayaçtır. Bundan milyonlarca yıl önce yașamıș olan ve ölüp bataklık alanda biriken bitkisel kısımların bașkalașıma (metamorfizma) uğramasıyla meydana gelmektedirler. Kömürün yapısına bakıldığında kömürü meydana getiren bitkisel kısmın kaynağı (ağaç kökü, dalı, yaprağı, spor ve reçineler vs.) dolayısıyla kömür yapısında gözle görünür (maseraller) ve gözle görünemeyen (litotipler) bantlı yapılar olușur.

Kömürün kısa ve elementel analiz bileșenleri yanı sıra, kömürün petrografik yapısındaki bu maseral ve litotip bileșenleri de kömürleșme derecesine bağlı olarak değișim göstermekte ve kömürlerin ısıl değerliklerini etkilemektedir. Sarma ve diğ. (2012) yaptıkları çalıșmada, vitrinit, liptinit ve inertinit miktarlarının ısı değer üzerindeki etkisini ortaya koymușlardır. Bu çaııșmaya göre, vitrinit ve liptinit oranı artıkça kömür ısıl değerinin arttığı ifade edilmiștir (Șekil 3).

\section{DEĞERLENDIRME ve TARTIȘMA}

\section{Değerlendirmede Kullanılan Numuneler ve Özellikleri}

Kömür Bileșenleri-üst ısıl değer ilișkisinin incelendiği bu çalıșma kapsamında, iTÜ Cevher Hazırlama Mühendisliği Bölümü Arșivinde bulunan (büyük bir çoğunluğu yazarın kendi çalıșmaları sonucunda elde edilmiștir) bazı kömür özelliklerinden yararlanıımıș olup, değerlendirmeye alınan kömürler ve özellikleri Çizelge 4. de verilmiștir.

Bazı kömür örneklerine ait farkı kül ve kalorifik değer içeriklerine sahip kömürler detaylı zenginleștirme ișlemleri sonucu üretilmiștir. Kömürlerin kısa analizleri ITÜ Maden Fakültesi, Cevher Hazırlama Mühendisliği laboratuarlarında yapılmıștır. 
Çizelge 2. Kısa kömür analizi bileșenleri-üst ısıl değer ilișkisine ait bazı modeller. Not: Isıl değerler üst ısıl değeri ifade etmektedir.

Figure 2. Some models established based on the relationship between proximate analysis constituents and gross calorific value.

\begin{tabular}{|c|c|c|}
\hline Araștırmacı ${ }^{y ı l}$ & Model & $\mathbf{R}^{2}$ \\
\hline Kathiravale ve diğ. ${ }^{2003}$ & $G C V=0.3080 V_{M}+0.4536 F_{C}-4.5421$ & 0.90 \\
\hline Thipkhunthod ve diğ. ${ }^{2005}$ & $G C V=0.4329]_{-}\left(V I_{M}+F_{C}\right)-7.3695$ & 1.00 \\
\hline Majumder ve diğ. ${ }^{2008}$ & $G C V=-0.0898 M+0.2695 V_{M}+0.3909 F_{C}-0.0082 A$ & 0.97 \\
\hline Erol ve diğ. ${ }^{2010}$ & $G C V=0.4013 F_{C}+0.0008 F_{C}^{2}+0.0065 V_{M}^{2}+0034 A^{2}-1.8925$ & 1.00 \\
\hline Yin 2011 & $G C V=0.2076 V_{M}+0.4188 F_{C}$ & 1.00 \\
\hline Mohammedet ve diğ. ${ }^{2014}$ & $G C V=0.4777 * F_{C}+0.3459 * V_{M}+0.10401 * A-8.5078$ & 1.00 \\
\hline
\end{tabular}

Not: Isıl değerler üst ısıl değeri ifade etmektedir.

Çizelge 3. Elementel kömür analizi bileșenleri-üst ısıl değer ilișkisine ait bazı modeller.

Figure 3. Some models established based on the relationship between ultimate analysis constituents and gross calorific value.

\begin{tabular}{|c|c|c|}
\hline Araștırmacı Yıl & Model & $\mathbf{R}^{2}$ \\
\hline Toscana ve diğ. ${ }^{2009}$ & $G C V=0.3542(C+2 H)$ & 0.924 \\
\hline Callejón-Ferre ve diğ. ${ }^{2011}$ & $\begin{array}{c}G C V=0.4346 C+0.1069 H-1.8669 \\
G C V=0.4255 C+0.1107 \mathrm{H}-0.4943 \mathrm{~N}-1.9018 \\
G C V=0.0037 C^{2}+10.7128 \\
G C V=0.4351 C-3.8748 / H^{-0.5639} \\
G C V=0.3583[C-30 / 8]+0.0605[0 / 4]\end{array}$ & $\begin{array}{l}0.996 \\
0.999 \\
0.995 \\
0.917 \\
0.936\end{array}$ \\
\hline Yin 2011 & $G C V=0.4216 \mathrm{C}-0.1126 \mathrm{H}$ & 0.998 \\
\hline Chelgani ve Makaremi ${ }^{2013}$ & $G C V=-1.2079+0.9909 H+0.3658 C+0.0 .3201 N-0.1068 O+0.1297 S$ & 0.996 \\
\hline Ghugare ve diğ..$^{2014}$ & $G C V=0.4312 C-\frac{0.2187 O}{10.7128+0.0037 C^{2}}+\frac{-0.0049 C * H+0.9167}{7.7302 H-0.0192 C O}+\frac{15.5016}{7.9623+14.3751 N}-\frac{38.4206}{22.8214+0.4276 S}$ & 0.995 \\
\hline Roberto ve diğ. ${ }^{2014}$ & $\begin{array}{c}G C V=0.4211 C-0090 O+0.1800 S-0.8081 \\
G C V=-0.0008 C^{2}+0.5179 C-3.4488\end{array}$ & $\begin{array}{l}0.993 \\
0.990\end{array}$ \\
\hline Setyewati ve diğ. ${ }^{2015}$ & $G C V=35.2572+0.6221 H+0.0682 \mathrm{~N}-0.2320 \mathrm{~S}-0.4681 \mathrm{O}-0.3722 \mathrm{~A}$ & 0.912 \\
\hline Matin ve Chehreh ${ }^{2016}$ & $G C V=-3.5393+0.2475 H+0.4254 C+0.7001 N+0.2724 S$ & 0.979 \\
\hline
\end{tabular}

Not: Isıl değerler üst ısıl değeri ifade etmektedir.

\section{Kül-Üst ısıl değer ilișkisinin irdelenmesi}

Değerlendirmenin bu kısmında, kül-ısıl değer (üst) ilișkisi incelenmiș ve her bir kömür numunesi örneği için kül-üst ısıl değer ilișkisi Zonguldak, Trakya, Ankara, Kütahya ve Soma bölgesi kömürleri için Șekil 4-8'de örneklendirilmiștir.
Görüldüğü üzere diğer bileșenlerin etkileri sabit tutulduğunda, genelde kül yapıcı madde, kömür üst ısıl değerini doğrudan etkilemekte ve kül-ısıl değer arasında lineer doğrusal bir ilișki bulunmaktadır. Külkalorifik değer korelasyonları çok yüksek değerlerde çıkmıștır. 


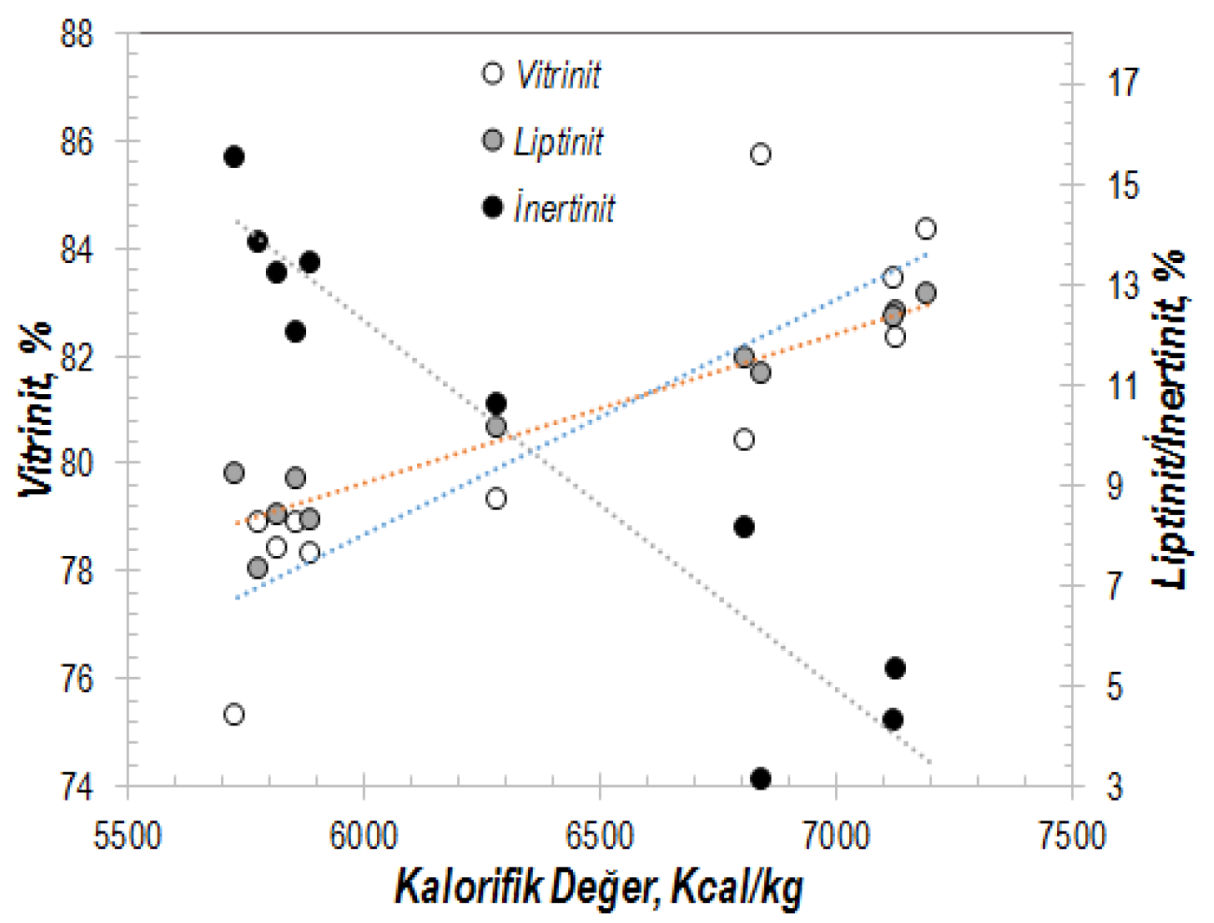

Șekil 3. Kömürün Petrografik yapısının Isıl değer üzerindeki Etkisi (Sarma ve diğ, 2012).

Figure 3. The Effect of Coal Petrography on Calorific Value of Coals (Sarma ve diğ, 2012).

\section{Farklı boyut gruplarında kül-ısıl değer ilișkisinin irdelenmesi}

Kömür külü-üst ısıl değer arasında, kömür boyut grubuna bağlı olmaksızın, genelde lineer bir ilișki olduğu yukarıda açıklanmıștır. Ancak, kömürün yapısındaki inorganik maddeler, kömür boyutlandırmasına bağlı olarak, farklı boyut gruplarında toplanabilmektedir. Bu durum, inorganik maddenin ufalanma karakteristiklerinden kaynaklanmaktadır. Bununla birlikte yukarıda ifade edilen davranıș, kömür yapısı içerisinde serbest halde olmayan, bünye külü olarak nitelendirilen inorganik madde varlığından kaynaklanabilmektedir. Bu tür bir değerlendirmeye ait örneklendirme ise Büyükdüz, Deniș LG ve SLi kömürleri üzerinde yapılmıș ve Șekil 9-11'de gösterilmiștir.

Șekil 9'da gösterilen Büyükdüz kömürü örneğinde, farklı boyut gruplarında yapılan zenginleștirme sonucunda elde edilen ürünler üzerinde yapılan külkalorifik değer tayini sonrasında kurulan ilișki değerlendirilecek olursa, hemen hemen tüm boyut grupları için kül-kalorifik değer ilișkisinin benzer olduğu gözlemlenmektedir.

Deniș kömürü değerlendirildiğinde ise (Șekil 10) düșük kül içerikli fraksiyonlarda tüm boyut grupları için kül-kalorifik değer ilișkisinin benzer olduğu ancak, özellikle yüksek kül içerikli fraksiyonlarda bu benzerliğin bozulduğu anlașılmaktadır. Kömürün organik kısmı kömürleșme ile ilișkili olduğundan, her boyut grubu için organik bileșenlerin benzer özellik gösterdiği, ancak, kömür yapısında bulunan inorganik madde türünün boyut grubuna bağlı olarak farklı boyut fraksiyonlarında toplandığı söylenebilir.

SLí kömürü üzerinde kül-ısıl değer ilișkisi incelenecek olursa (Șekil 11) gerek düșük kül içerikli gerekse yüksek kül içerikli ürünlerin kül-ısıl değer ilișkisinin birbirinden farklı olduğu saptanmıștır. Bu durum, gerek kül yapıcı maddenin farklı boyut gruplarında ayrı ayrı toplanmasından kaynaklanmakta, gerekse kömürün organik kısmının farklı yapılardan (Maseraller) oluștuğunu göstermektedir. Bu durumun iyice anlașılabilmesi için, organik kısmın analizinin detaylı olarak yapılması gerekmektedir.

Deneysel çalıșmalarda değerlendirmeye alınan tüm kömür örnekleri üzerinde gerçekleștirilen kül-kalorifik değer ilișkisi Șekil 12‘de verilmiștir.

Șekil 12'den görüleceği üzere değerlendirmeye alınan tüm kömür örneklerinin bireysel olarak külkalorifik değer ilișkisinin yüksek regresyonda oldu- 
Çizelge 4 Tüvenan kömür numunelerinin standart kömür analizleri (Kuru baz).

Figure 4. Proximate analysis of some Turkish ROM Coals (dry base).

\begin{tabular}{|c|c|c|c|c|c|c|}
\hline Numuneler & $\begin{array}{c}\text { M } \\
(\%)\end{array}$ & $\begin{array}{c}\mathrm{K} \\
(\%)\end{array}$ & $\begin{array}{l}\text { UM } \\
\text { (\%) }\end{array}$ & $\begin{array}{l}\text { SK } \\
\text { (\%) }\end{array}$ & $\begin{array}{c}\mathbf{S} \\
(\%)\end{array}$ & KD \\
\hline Seyitömer Linyit İșl. (SLi) & 31.1 & 53.7 & 26.70 & 19.60 & 0.85 & 1703 \\
\hline Çan Linyit İşletmesi (ÇLí) & 22.6 & 27.6 & 40.76 & 31.64 & 5.63 & 4225 \\
\hline Soma -10 mm (Eski Gürmin) & 15.6 & 32.5 & 43.70 & 9.98 & 0.83 & 3638 \\
\hline Soma +10 mm (Eski Gürmin) & 9.3 & 53.2 & 39.70 & 7.10 & 0.18 & 1390 \\
\hline Eynez Yeraltı (EYA) & 12.3 & 32.9 & 38.70 & 28.40 & 0.71 & 3630 \\
\hline Büyükdüz (BYDZ) & 9.1 & 44.4 & 28.60 & 27.00 & 1.03 & 3082 \\
\hline Yörgüç (YRÇ) & 17.6 & 47.8 & 28.30 & 24.20 & 2.27 & 2007 \\
\hline Dragline BHY3 & 9.8 & 53.7 & 29.11 & 17.20 & 0.7 & 2655 \\
\hline 48C Pano & 12.9 & 39.4 & 32.24 & 28.36 & 1.46 & 3716 \\
\hline Ömerler Yer Altı (ÖYA) & 11.2 & 48.7 & 30.1 & 21.20 & 0.89 & 2336 \\
\hline Deniș Lavvara Giden (DLG) & 18.1 & 20.3 & 43.31 & 36.39 & 1.2 & 3780 \\
\hline Deniș Termiğe Giden DTG & 23.7 & 28.4 & 42.60 & 29.00 & 1.51 & 3788 \\
\hline Tunçbilek-BYJ & 9.6 & 39.0 & 48.20 & 12.80 & 1.65 & 3944 \\
\hline Soma İmbat (IMB) & 8.0 & 49.0 & 29.50 & 21.50 & 0.21 & 1534 \\
\hline Soma İmbat Doğu Pano (IMBD) & 8.4 & 37.1 & 33.74 & 29.16 & 0.54 & 3062 \\
\hline Ișıklar (IȘKL) & 17.2 & 40.2 & 48.30 & 11.50 & 0.27 & 2730 \\
\hline Eynez Açık Ocak (EAO) & 11.8 & 26.9 & 38.80 & 34.30 & 0.47 & 3927 \\
\hline Soma Sarıkaya (SRKY) & 15.8 & 42.7 & 30.90 & 26.40 & 0.44 & 2544 \\
\hline Muğla Eskihisar (ESKH) & 15.5 & 26.2 & 39.96 & 33.84 & 1.65 & 2687 \\
\hline Tınaz (TNZ) & 11.8 & 44.9 & 44.56 & 10.54 & 1.83 & 1537 \\
\hline İkizköy (IKKZ) & 15.6 & 26.8 & 50.00 & 23.20 & 2.91 & 2010 \\
\hline Belentepe (BTP) & 13.4 & 45.3 & 51.70 & 3.00 & 3.89 & 3407 \\
\hline Hüsamlar (HUS) & 16.2 & 36.3 & 46.83 & 16.87 & 3.64 & 3539 \\
\hline Bursa Orhaneli $(\mathrm{OHN})$ & 12.6 & 25.4 & 39.80 & 34.80 & 3.25 & 3975 \\
\hline Bursa Keles (KLS) & 26.8 & 19.4 & 36.66 & 43.94 & 2.85 & 3267 \\
\hline Amasra (AMSR) & 3.93 & 38. & 28.25 & 32.2 & - & 4591 \\
\hline Tekirdağ Malkara (UYS) & - & 54.1 & 29.5 & 16.43 & 1.49 & 2345 \\
\hline Ankara Çayırhan Park1 & - & - & - & - & - & - \\
\hline Ankara Çayırhan Park2 & - & - & - & - & - & - \\
\hline
\end{tabular}

K, UM, SK ve ısıl değerleri kuru baza göre hesaplanmıștır. (K: Kül, UM : Uçucu Madde, SK: Sabit Karbon) 


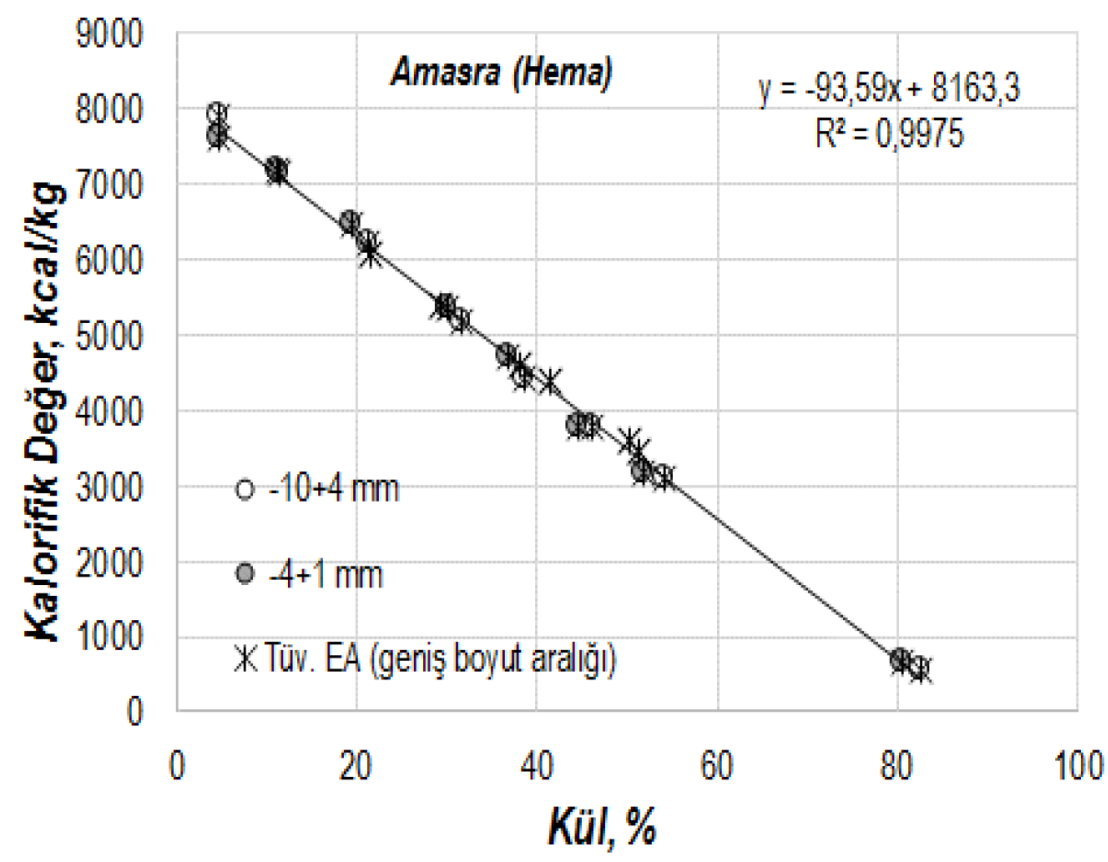

Șekil 4. Amasra Bölgesi Kömürü Kül-Kalori Değeri Ilișkisi.

Figure 4. Relationship Between Ash Content and Calorific Value for Amasra Coal.

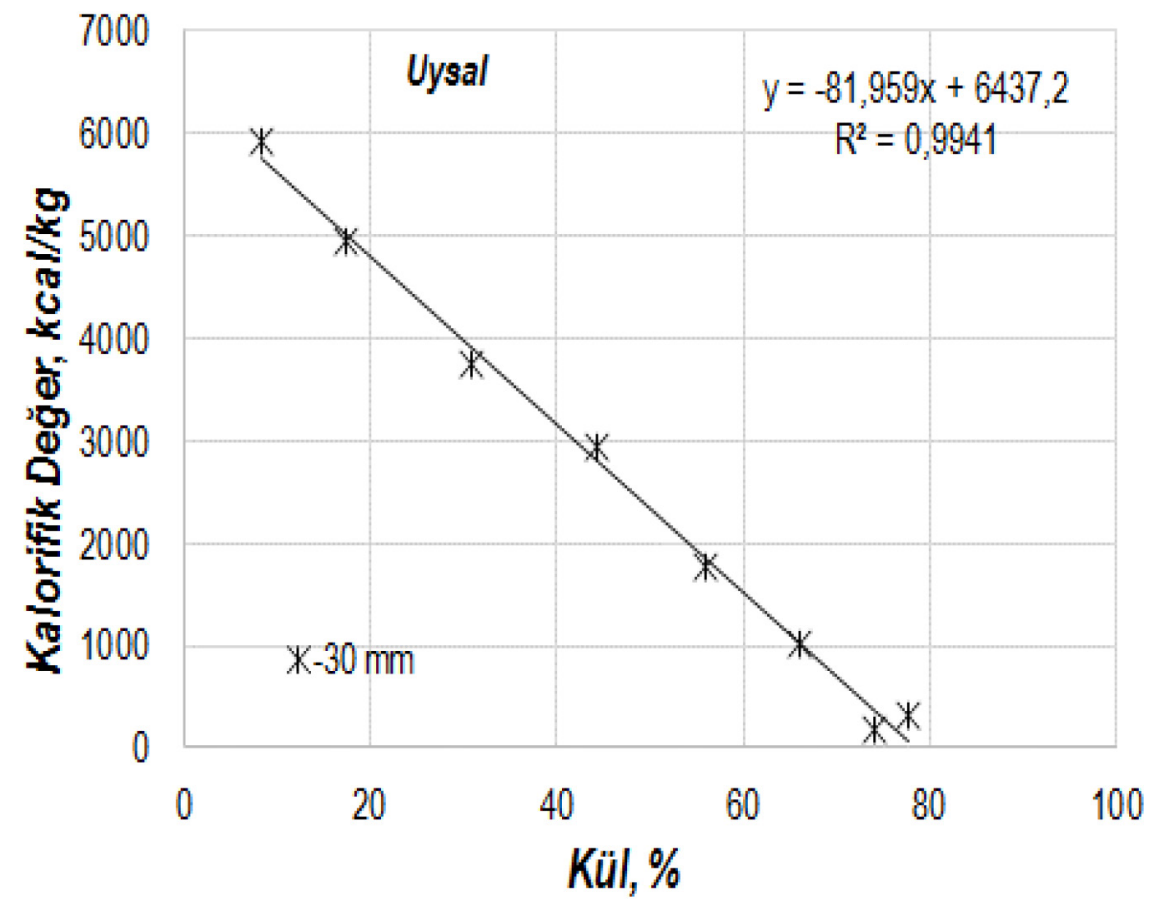

Șekil 5. Trakya Bölgesi Kömürü Kül-Kalori Değeri İlișkisi.

Figure 5. Relationship Between Ash Content and Calorific Value for Thracian Coals.

ğu, ancak kömürler arasında ortak bir kül-kalorifik değer ilișkisinin kurulmasının mümkün olmadığı gözükmektedir. Değerlendirmeye alınan kömür örnekleri yüksek ranklı (Amasra bitümlü), yarı bitümlü
(Kütahya ve Soma bölgesi kömürleri) ve düșük ranklı kömürleri-linyitleri içermektedir. Her bir kömür örneğinin içerdiği inorganik madde türü gerek olușum açısından gerekse mineral madde türü açısından 


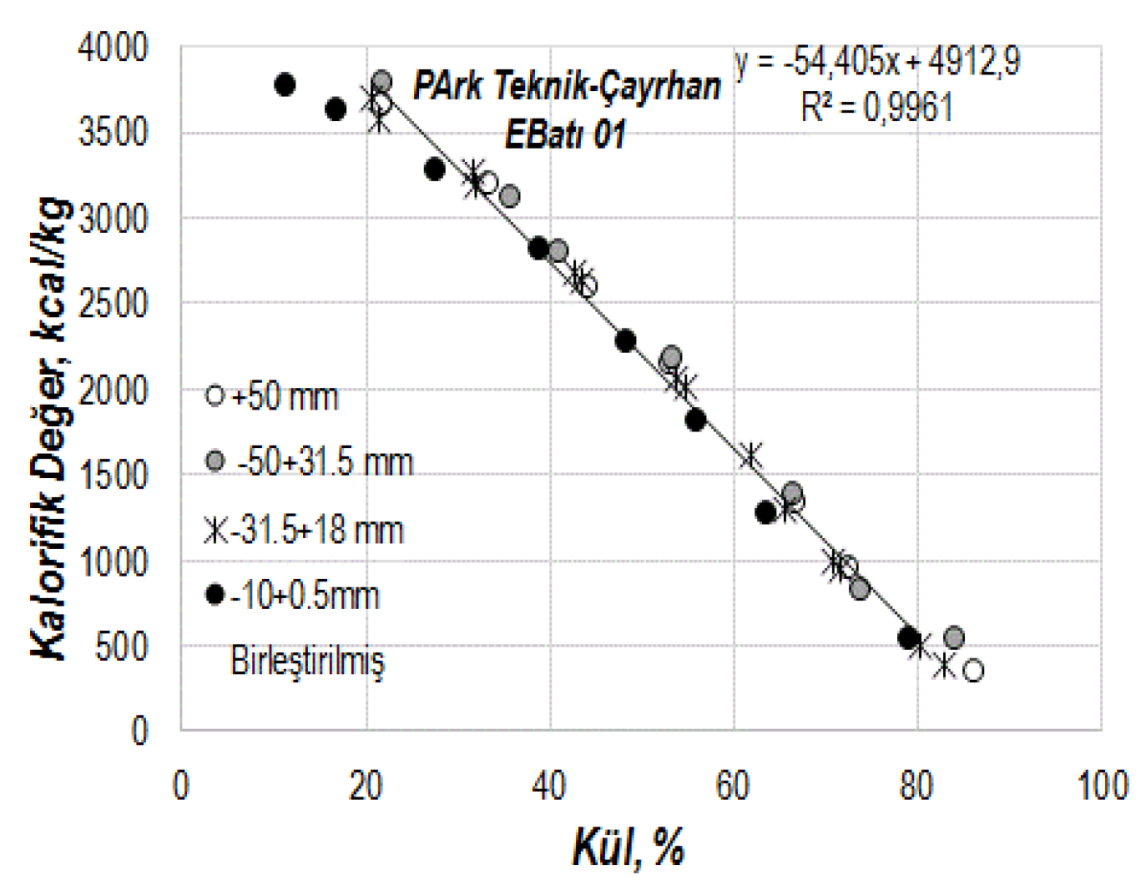

Șekil 6. Ankara Bölgesi Kömürü Kül-Kalori Değeri ilișkisi.

Figure 6. Relationship Between Ash Content and Calorific Value for Ankara (Çayırhan) Coals.

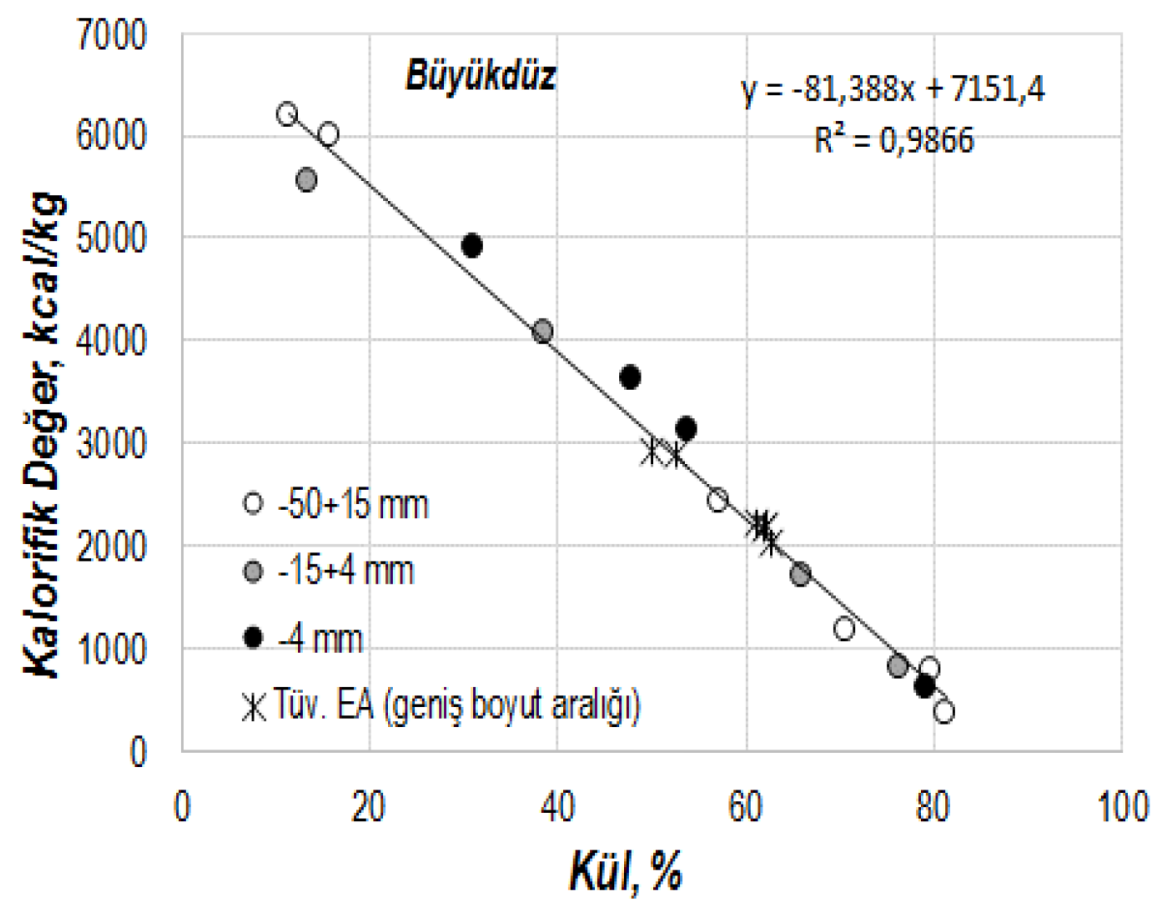

Șekil 7. Kütahya Bölgesi Kömürü Kül-Kalori Değeri Ilișkisi.

Figure 7. Relationship Between Ash Content and Calorific Value for Kütahya Coals.

farklılık göstermektedir. Dolayısıyla, gerek yüksek kül, gerekse düșük kül içerikli kömür ürünleri arasında kalorifik değer açısından büyük farklar olușmuștur.
Yüksek kül içerikli ürünlerdeki ısıl değer değișimi mineral madde türü ve mineral madde olușumu (bünye külü ya da serbest kül) arasındaki farklılıklardan 


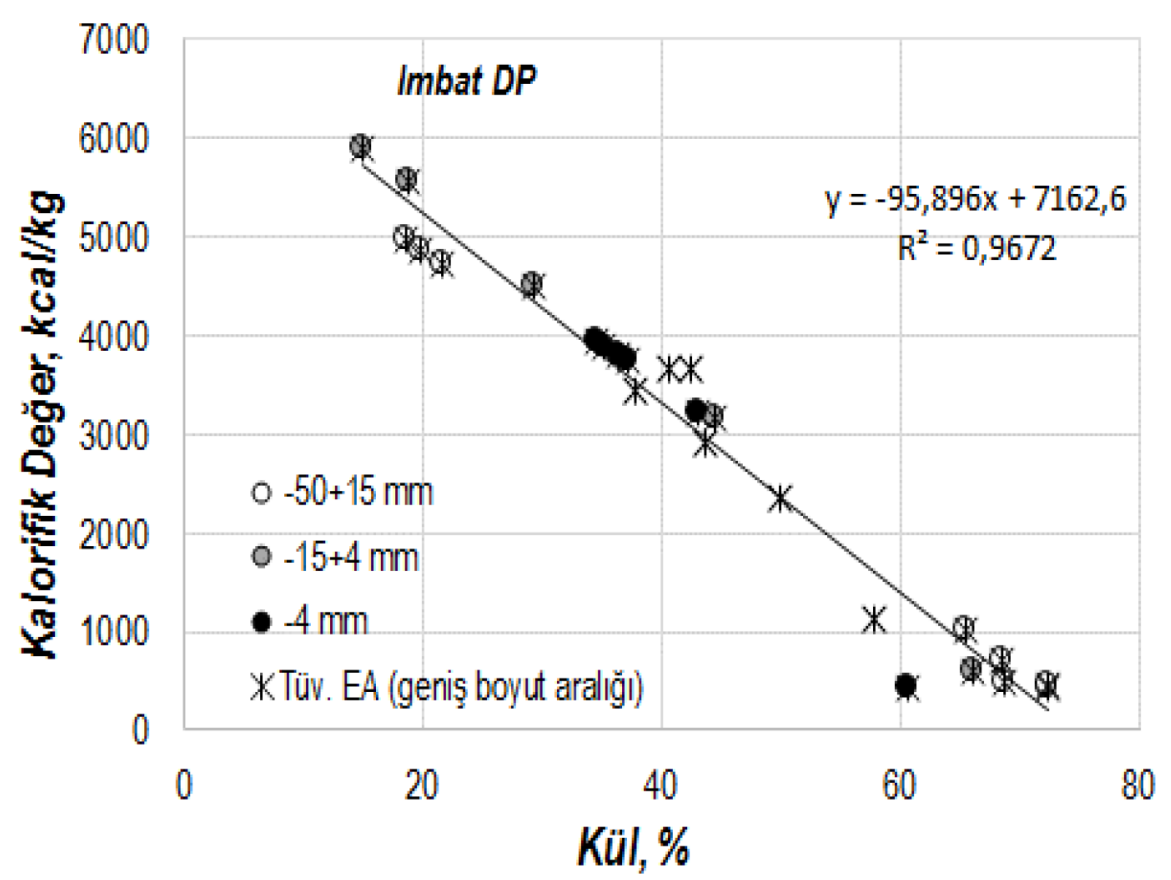

Șekil 8. Soma Bölgesi Kömürü Kül-Kalori Değeri Ilișkisi.

Figure 8. Relationship Between Ash Content and Calorific Value for Soma Coals.

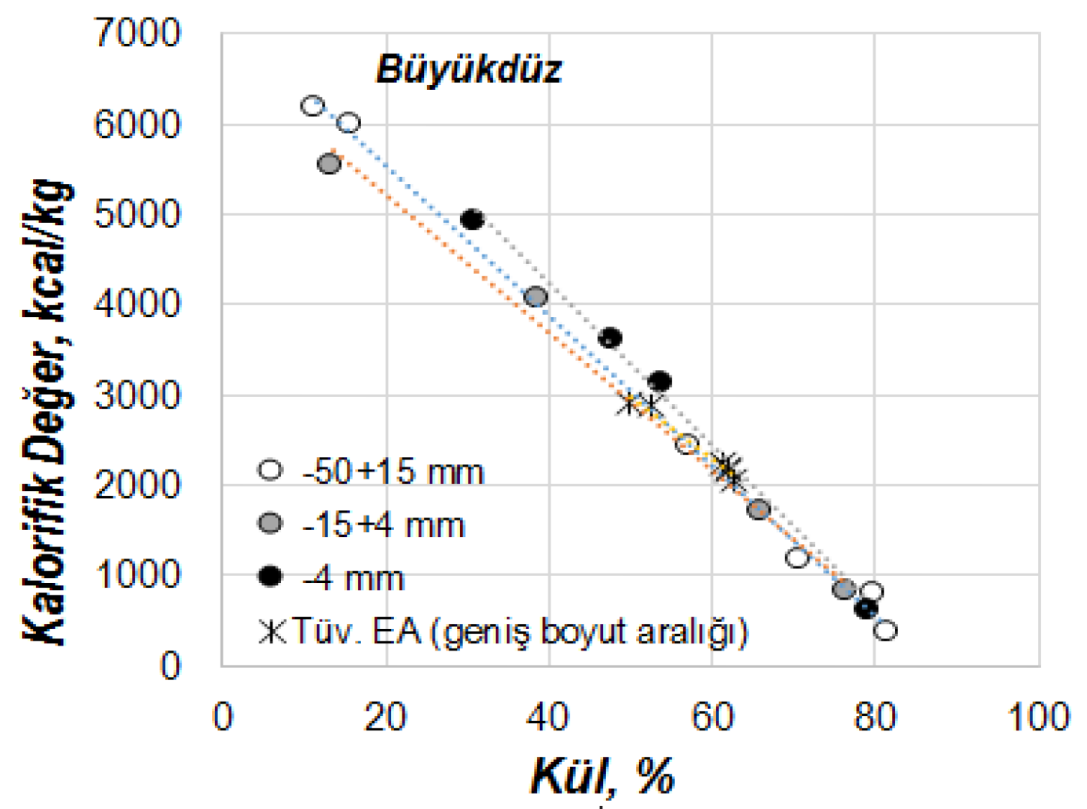

Șekil 9. Büyükdüz Kömürü Boyuta göre Kül-Kalori Değeri Ilișkisi.

Figure 9. Relationship Between Ash Content and Calorific Value for Büyükdüz Coal.

kaynaklanmaktadır. Özellikle, kızdırma kaybı yüksek olan kalsit, ankerit vs gibi kalsiyum karbonatlı kül yapıcı maddeleri içeren ürünlerde, düșük kül içeriği gözlenmesine rağmen, karșılık gelen kalorifik değerlerin düșük olduğu görülmüștür.
Öyle ki, atılabilir șist kalitesi için kalorifik değer $<500$ $\mathrm{kcal} / \mathrm{kg}$ olarak düșünülürse $500 \mathrm{kcal} / \mathrm{kg}$ den daha düșük ısıl değerlikli șistlerin kül içerikleri \% 65-83 arasında değișim göstermiștir. Yani diğer bir deyișle, atılabilir kalitede șist üretimi için kül değerlerinin 


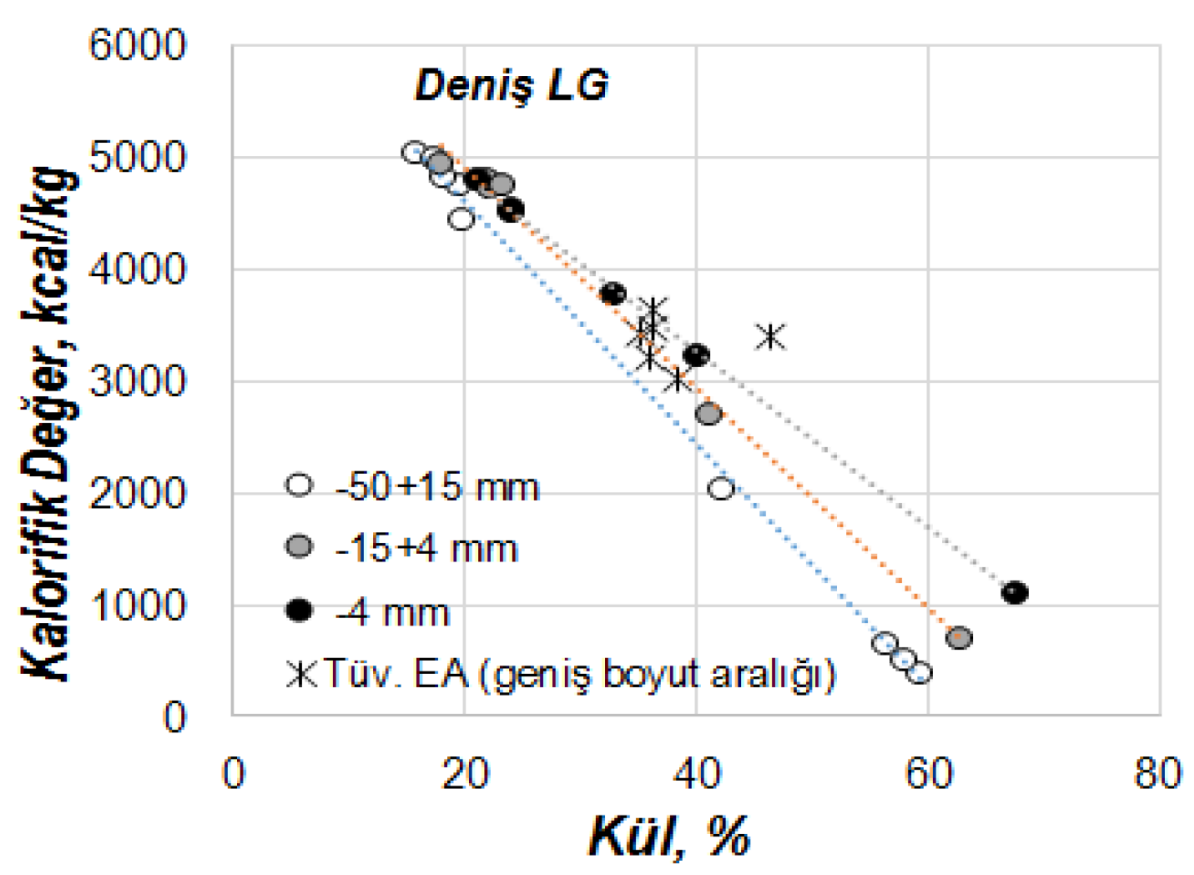

Șekil 10. Deniș (LG) Kömürü Boyuta göre Kül-Kalori Değeri Ilișkisi.

Figure 10. Relationship Between Ash Content and Calorific Value for Deniș (Washery feed) Coal.

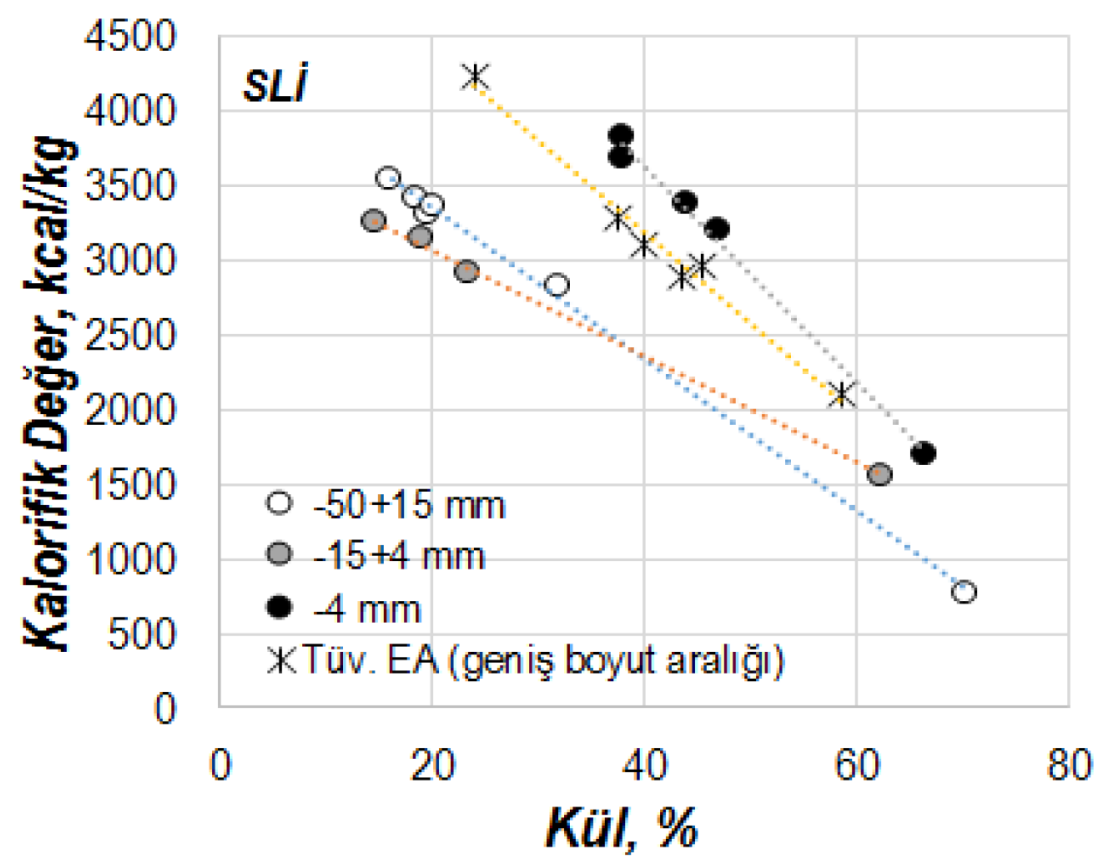

Șekil 11. Seyitömer Kömürü Boyuta göre Kül-Kalori Değeri Ilișkisi.

Figure 11. Relationship Between Ash Content and Calorific Value for Seyitömer Coal.

Kütahya bölgesi kömürleri uygulamasında \% 83, Soma bölgesi kömürleri uygulamasında \% 65 civarında olması beklenmektedir. Değerlendirmede kullanılan 4 farklı kömür külünün kimyasal analizi Çizelge 5 'te verilmektedir.
Düșük kül içerikli kömür ürünlerinin kül-kalorifik değer ilișkisi incelenecek olursa, SLi, Uysal (Trakya bölgesi) ve Deniș LG (Soma bölgesi), Park teknik (Çayırhan Bölgesi) kömürleri gibi düșük ranklı kömürlerin aynı kül değerleri için daha düșük ısıl değerlikli 


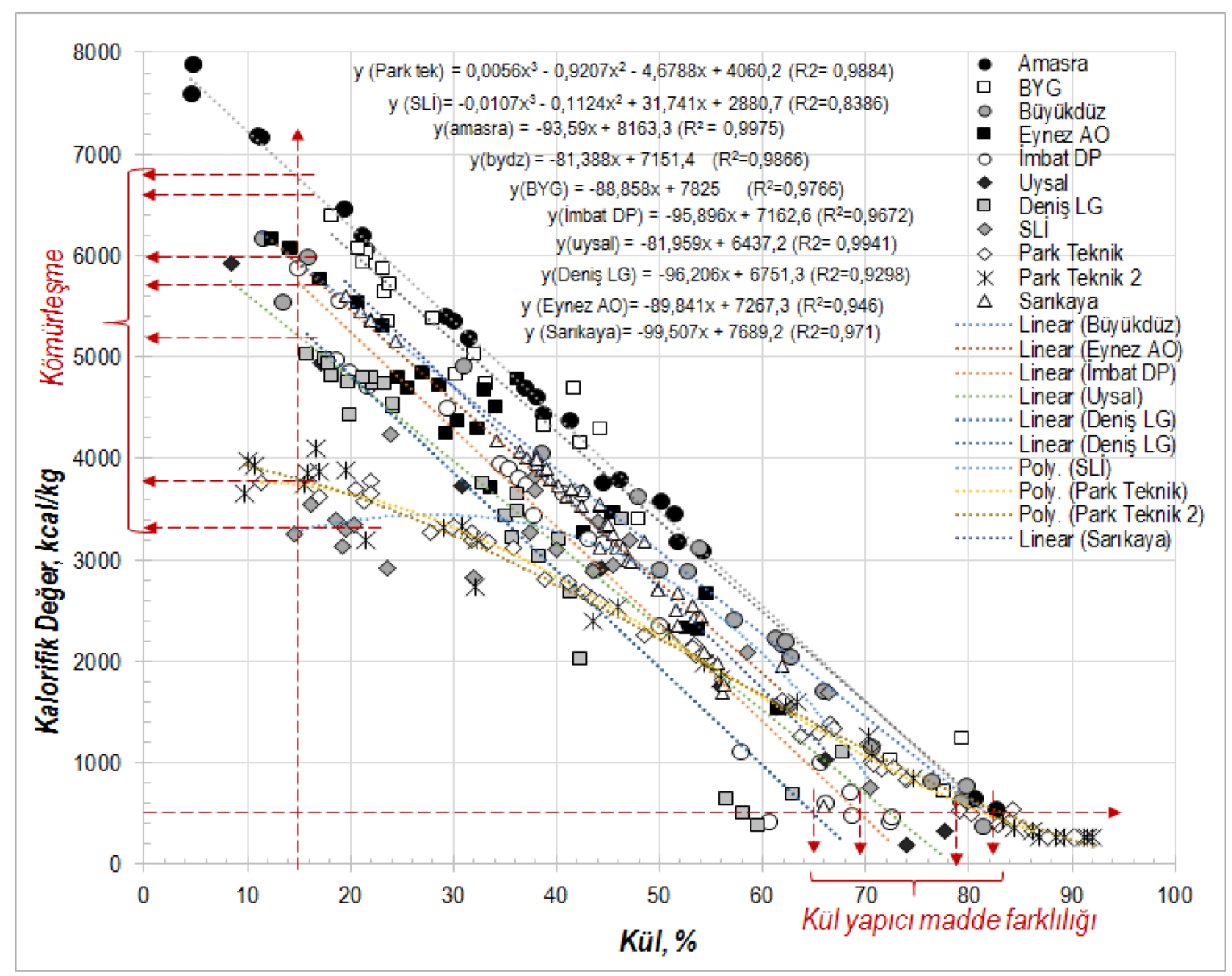

Şekil 12. Farklı Türk Kömürlerine ait Kül-Kalori Değeri İlișkisi .

Figure 12. Relationship Between Ash Content and Calorific Value for Coals from Different Coal Deposits in Turkey.

Çizelge 5. Toplu grafikte verilen Kömür örneklerinden bazılarına ait Kimyasal analiz Sonuçları

Figure 5. Chemical analysis results of some Turkish Coals at summarized and detailed graphics given above.

\begin{tabular}{ccccc}
\hline Bileșen, \% & Deniș LG & İmbat DP & BYKDZ & SLi \\
\hline $\mathrm{SiO}_{2}$ & 24.54 & 48.37 & 54.66 & 62.63 \\
$\mathrm{Al}_{2} \mathrm{O}_{3}$ & 11.67 & 14.17 & 15.46 & 18.42 \\
$\mathrm{Fe}_{2} \mathrm{O}_{3}$ & 4.16 & 2.29 & 10.40 & 7.62 \\
$\mathrm{MgO}$ & 2.00 & 1.60 & 5.37 & 3.36 \\
$\mathrm{CaO}$ & 43.65 & 24.20 & 1.93 & 1.84 \\
$\mathrm{Na}_{2} \mathrm{O}$ & 0.18 & 1.25 & 0.16 & 0.80 \\
$\mathrm{~K}_{2} \mathrm{O}$ & 0.61 & 1.28 & 1.79 & 1.93 \\
$\mathrm{TiO}_{2}$ & 0.41 & 0.42 & 0.72 & 0.14 \\
$\mathrm{P}_{2} \mathrm{O}_{5}$ & 0.13 & 0.20 & 0.14 & 0.11 \\
$\mathrm{MnO}$ & 0.05 & 0.03 & 0.18 & 0.08 \\
$\mathrm{Cr}_{2} \mathrm{O}_{3}$ & 0.012 & 0.008 & 0.067 \\
\hline
\end{tabular}


ürünler sunduğu görülmüștür. Bu durum tamamıyla kömürleșme derecesiyle ilgilidir.

Kömürleșme derecesi kısa ve elementel analizlerde yer alan sabit karbon, uçucu madde, nem, oksijen, hidrojen, azot ve sülfür içerikleri gibi bileșenler tarafından kontrol edilmektedir.

Dolayısıyla, kısa kömür ve elementel analiz bileșenlerinin etkisi bir sonraki bölümde tartıșılmıștır.

\section{Bazı Türk kömürleri üzerinde, Kısa Analiz kömür bileșenleri-ısıl değer ilișkisinin irdelenmesi}

Kısa Kömür analiz bileșenleri-ısıl değer ilișkisinin değerlendirilmesi 15'den fazla Türk kömürü kullanılarak, karșılaștırmalı olarak, Șekil 13' de yapılmıștır.

Șekil 13'den gözleneceği üzere literatürde yer alan ve birçok araștırmacı tarafından kurulmuș olan kısa kömür analiz bileșenleri-ısıl değer ilișkilerinden, yüksek regresyonlu olanları seçilmiș ve uygulanmıș olmasına rağmen, modellerin ancak, kaba bir yaklașım gösterebildikleri, en iyi yaklașım gösteren modelin Parikh ve arkadașları (2005) tarafından sunulan model olduğu anlașılmıștır. Ancak bu modelde dahi, hata payı \% 8 civarında çıkmıștır. Bu modele göre yapılacak olan değerlendirmenin özellikle yüksek ısıl değerlikli kömürlerin modellenmesinde büyük farklar yaratacağı așikardır. Kısa kömür bileșenleri ve kül içeriği-üst ısıl değer ilișkisindeki kaba yaklașımların ve yüksek hata paylarının nedeninin, kömür maseral yapısıyla ilgili olduğu düșünülmüștür. Dolayısıyla daha güçlü bir modelin kurulması için kısa kömür, elementel ve petrografik analiz verilerinin birlikte değerlendirilebildiği modellerin kurulması gerektiği düșünülmektedir.

\section{SONUÇLAR ve ÖNERILER}

Kısa kömür analiz bileșenleri-üst ısıl değer ilișkisinin tartıșıldığı bu çalıșmada bireysel kömür örnekleri için kül-ısıl değer ilișkisinin yüksek yaklașımla kurulabileceği, kül içeriğinin artıșına bağlı olarak kömür ısıl değerinde lineer bir azalma olduğu anlașılmıștır. Ancak,

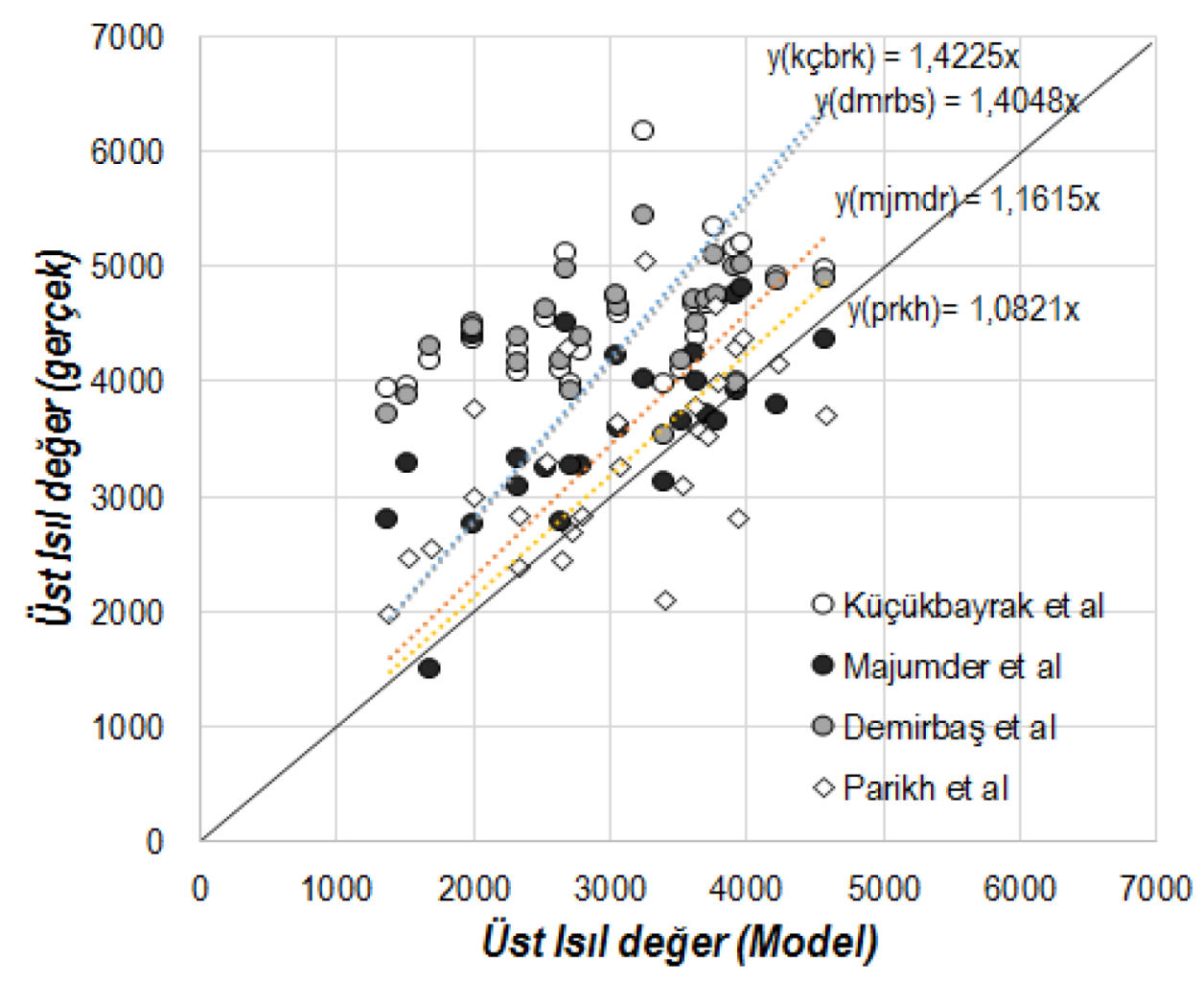

Şekil 13. Farklı Türk Kömürleri Kullanılarak, Kısa Kömür analiz bileșenleri-ısıl değer ilișkisinin farklı modellere göre değerlendirilmesi.

Figure 13. Evaluation of Relationship Between Proximate Analysis Constituents and Calorific Value Based on Models Proposed by Different Researchers. 
kömür içerisindeki inorganik madde türlerinin farklı boyut gruplarında ayrı ayrı yığılma gösterebileceği ve bu davranıșın da boyuta bağlı olarak kül-ısıl değer ilișkisinin etkileyeceği saptanmıștır.

Farklı Türk kömürleri üzerinde gerçekleștirilen külısıl değer ilișkisi değerlendirilmesi yapılmıș ve kül-ısıl değer ilișkisinin kömürden kömüre farklılık gösterdiği anlașılmıștır. Bunun nedenleri olarak özellikle yüksek kül içerikli ürünlerde inorganik madde türünden kaynaklanan ve çoğunlukla kızdırma kaybının etken olduğu farklııktan kaynaklandığı, düșük kül içerikli ürünlerin ısıl değerlerinin kömüre bağlı olarak farklık göstermesinin ise kömürleșme derecesinden kaynaklandığı anlașılmıștır.

Kömürleșme derecesi, kısa kömür ve elementel kömür analizlerinde yer alan uçucu madde, sabit karbon bileșenleri ile petrografik analiz bileșenlerinde yer alan, maseral grupları ile belirlenmekte olup, kömürleșme derecesinden kaynaklanan, yukarıda ifade edilen özelliklerin değișim göstermesi sonucunda, doğal olarak kömür kalitesini ve birim karbon bazında vereceği ısıl değerin doğrudan etkilendiği de örneklerle tartıșılmıștır.

Yukarıda açıklanan sonuçlara dayanarak herhangi bir kömürün kalitesinin sadece kül içeriği ile tanımlanmasının eksik olacağı, kalorifik değerinin de ifade edilmesi gerektiği anlașılmıștır. Özellikle kömür yıkama ișlemleri sonrasında yine ürün kalitesinin sadece kül içeriği ile değil kalorifik değer ile de tanımlanması gerektiği anlașılmıștır. Bununla birlikte özellikle termik santrallere kömür beslemesi yapilırken, kömür ısıl değerinin X-ray cihazlarıyla tanımlanmasının zor olacağı, bu tanımlamanın bireysel kömür örnekleri için mümkün olacağı ancak global bir kömür bileșenleri-ısıl değer tanımlamasının yüksek uyumluluk dereceleriyle yapılamayacağı anlașılmıștır.

\section{KAYNAKLAR}

Ateșok, G., 2005. Kömür Hazırlama ve Teknolojisi, 975-7946-22-2, İstanbul.

Benson, S.A., Jones, M.L. and Harb, J.N., 1993. Ash formation and deposition. In Smoot, L.D. (Ed), Fundamentals of Coal Combustion for Clean and Efficient Use, Coal Science and Technology 20, Elsevier Science Publishers, Amsterdam, ISBN 0-444-89643- 0, Chapter 4, pp. 299-373.
Callejón-Ferre, A.J., Velázquez-Martí, B., LópezMartínez, J.A., Manzano-Agügliaro, F., 2011. Greenhouse crop residues: energy potential and models for the prediction of their higher heating value, Renew Sust Energy Rev, 15, 948-955.

Chelgani, S.C. and Makaremi, S., 2013. Explaining the relationship between common coal analyses and Afghan coal parameters using statistical modeling methods, Fuel Process Technol, 110, 79-85.

Ghugare, S.B., Tiwary, S., Elangovan, V., Tambe, S.S., 2014. Prediction of higher heating value of solid biomass fuels using artificial intelligence formalisms, Bioenergy Res., 7, 681-692.

Demirbaș, A., 1997. Calculation of Higher heating values of biomass fuels, Fuel, 76(5), 43.

Erol, M., Haykiri-Acma, H., Küçükbayrak, S., 2010. Calorific value estimation of biomass from their proximate analyses data, Renew Energy, $35,170-173$.

Feng, Q., Zhang, J., Zhang X. and Wen, S., 2015. Proximate analysis based prediction of gross calorific value of coals: A comparison of support vector machine, alternating conditional expectation and artificial neural network, Fuel Processing technology, 129, 120-129.

Kathiravale, S, Yunus, M.N.M., Sopian, K., Samsuddin, A.H., Rahman R.A., 2003. Modeling the heating value of municipal solid waste, Fuel, $82,1119-1125$.

Küçükbayrak, S., Duruș, B, Meriçboyu, A.E., Kadıŏ̆lu, E., 1991. Estimation of Calorific values of Turkish lignites, Fuel, 70, 979-81.

Majumder, A.K., Jain, Rachana, Banerjee, P., Barnwal, J.P., 2008. Development of a new proximate analysis based correlation to predict calorific value of coal, Fuel, 87, 3077-3081.

Matin, S.S., Chehreh, C.S., 2016. Estimation of coal gross calorific value based on various analyses by random forest method, Fuel, 177, 487-49.

Mohammed I.Y., Kazi F.K., Yusuf S.B., Alshareef I., Chi S.A., 2014. Higher heating value (HHV) prediction model from biomass proximate analysis data. International conference \& exhibition on clean energy, Quebec, 20-22. 
Parikh, J., Channiwala, SA, Ghosal, GK., 2005. A correlation for calculating $\mathrm{HHV}$ from proximate analysis of solids fuel, Fuel, 2005, 484-94.

Roberto, G., Consuelo, P., Antonio, G.L., 2014. Spanish biofuels heating value estimation. Part I: Ultimate analysis data, Fuel, 117, 11301138.

Setyawati, W., Damanhuri, E., Lestari, P., Dewi, K., 2015. Correlation equation to predict HHV of tropical peat based on its ultimate analyses, Procedia Eng, 125, 298-303.

Sharma, A., Saikia, B. K., Baruah, B. P., 2012. Maceral Contents Of Tertiary Indian Coals And Their Relationship With Calorific Values, Int.
Journal of Innovative Research and Developments, vol 1 (7), 196-203.

Thipkhunthod, P., Meeyoo, V., Rangsunvigit, P., Kitiyanan, B., Siemanond, K., Rirksomboon, T., 2005. Predicting the heating value of sewage sludges in Thailand from proximate and ultimate analyses, Fuel, 84, 849-857.

Toscano, G., Foppa, P.E., 2009. Calorific value determination of solid biomass fuel by simplified method, J Agricultural Eng, XL, 1-6.

Wen, X., Jian, S, Wang, J., 2017. Prediction models of calorific value of coal based wavelet neural networks, Fuel, 199, 512-522.

Yin, C.Y., 2011. Prediction of higher heating values of biomass from proximate and ultimate analyses, Fuel, 90, 1128-1132. 
